\section{RB985476 - a sugarcane cultivar with high agro- industrial yield and disease resistance}

\author{
Monalisa Sampaio Carneiro ${ }^{1^{*}}$, Roberto Giacomini Chapola ${ }^{1}$, \\ Antonio Ribeiro Fernandes Junior ${ }^{1}$, Danilo Eduardo Cursi ${ }^{1}$, \\ Thiago Willian Almeida Balsalobre ${ }^{1}$ and Hermann Paulo \\ Hoffmann ${ }^{1}$
}

\begin{abstract}
RB985476 has a high tillering capacity, excellent canopy cover, high longevity, high agro-industrial yield, medium to low fiber content and high germination capacity after mechanical harvesting. RB985476 is resistant to smut, brown and orange rusts and recommended for harvest in the middle growing season in the south-central region of Brazil.
\end{abstract}

Keywords: Saccharum spp., breeding, productivity.

\section{INTRODUCTION}

Sugarcane is an important crop for food and bioenergy production. Breeding programs around the world search for more productive cultivars and that meet the demands of agricultural and industrial production. The Federal University of São Carlos (UFSCar) had a sugarcane breeding program (PMGCA) recognized worldwide and that is part of the the Inter-University Network for the Development of Sugarcane Industry (RIDESA, www.ridesa.com.br). RIDESA is a network of ten public Federal Universities that have successfully developed sugarcane cultivars adapted to different environments and agricultural managements enabling cultivation in more than 9 million hectares in Brazil (Carneiro et al. 2016, Chapola et al. 2016, Daros et al. 2017, 2018, Carneiro et al. 2019). A new cultivar, RB985476, released by PMGCA/UFSCCar, has high tillering and excellent ratooning ability even under mechanized harvesting. In addition, this new cultivar is suitable for mechanical planting and is resistant to major sugarcane diseases.

\section{PEDIGREE AND BREEDING METHOD}

The RB985476 cultivar was originated from a full-sib cross between female H53-3989 and male RB855206 (Figure 1) performed in 1998 at the Flowering and Crossing Station of Serra do Ouro in the municipality of Murici, Alagoas state, Brazil (lat $9^{\circ} 14^{\prime} 35.7^{\prime \prime}$ S, long $35^{\circ} 50^{\prime} 15.2^{\prime \prime}$ W, alt $450 \mathrm{~m}$ asl). Sugarcane caryopses were germinated under controlled conditions in the same year as the crossing by the Sugarcane Breeding Program of the UFSCar on the grounds of the Centre for Agricultural Sciences (CCA) in the municipality of Araras, São Paulo state, Brazil. Seedlings were transplanted to the field for the first selection stage (T1), in which each genotype was selected in the
Crop Breeding and Applied Biotechnology 20(2): e304020210, 2020 Brazilian Society of Plant Breeding. Printed in Brazil http://dx.doi.org/10.1590/198470332020v20n2c26 
first ratoon for morphological traits such as higher stalk number, absence of flowering, reduced bagasse pith, and greater resistance to major diseases (Morais et al. 2015, Brasileiro et al. 2016).

The selected clones were then planted in an experimental trial consisting of an augmented block design (first clonal assessment trial - T2) (Federer 1956), together with several standard commercial cultivars, at two different locations in the state of São Paulo: Araras (lat $22^{\circ} 18^{\prime} 57.7^{\prime \prime} \mathrm{S}$, long $47^{\circ} 22^{\prime} 49.5^{\prime \prime} \mathrm{W}$, alt $707 \mathrm{~m}$ asl) and Valparaíso (lat $21^{\circ} 19^{\prime} 07.9^{\prime \prime} \mathrm{S}$, long $50^{\circ} 55^{\prime} 49.7^{\prime \prime} \mathrm{W}$, alt $460 \mathrm{~m}$ asl). Each experimental plot consisted of two

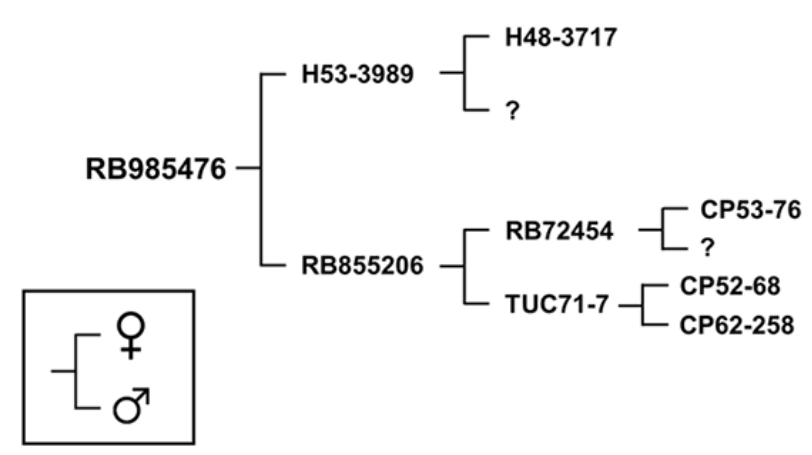

Figure 1. Pedigree of sugarcane cultivar RB985476. $2.5 \mathrm{~m}$ rows, with no replicates. Clones were evaluated in plant cane and in the first and second ratoon crops based on the same criteria as described in T1, as well as the stalk weight per plot (WP) and kilogram of brix per plot (KBP) (Balsalobre et al. 2016). Clones with desirable traits were selected and then planted in an augmented block design (Federer 1956) at five locations under different climate and soil conditions in separate regions of Sao Paulo state (Table 1). At this stage, plots consisted of two $5 \mathrm{~m}$ rows spaced $1.40 \mathrm{~m}$ apart, with two replicates. Selection was carried out based on the mean performance of both plant and ratoon crops across all environments. Selection criteria were similar to those in stage T2, with sucrose content (PC expressed in \%) and kilogram of pol per plot (KPP) considered as additional traits (Morais et al. 2015, Diniz et al. 2019).

At the completion of stage T3, the selected clones were planted in the final assessment trials (FAT), arranged in a randomized block design with three or four replicates. Standard commercial cultivars of intermediate/late maturation were used as controls and distributed within the blocks. A total of 14 experimental trials were distributed over several regions, each with distinctive soil and climate conditions. Data from three to four harvests (plant cane and two and/ or three ratoon crops) were analyzed (Table 1). Agronomic and agro-industrial traits evaluated at the final stage consisted of tons of cane per hectare (TCH), PC, tons of pol per hectare (TPH), and fiber content (\%). In addition, coefficient of environmental variation, effects of genotype $\times$ environment interaction, and clone adaptability and stability (Eberhart and Russell 1966) were estimated by individual (each site) and combined (all sites) analyses of variance. A maturation curve constructed from the most promising FAT clones was used to identify the best harvest period according to the PC.

Table 1. Locations of the third selection stage (T3) and final assessment trials (FAT) in São Paulo state, Brazil

\begin{tabular}{|c|c|c|c|c|}
\hline Locations & Latitude & Longitude & Altitude & Stage \\
\hline Sertãozinho & $21^{\circ} 08^{\prime} 16^{\prime \prime} \mathrm{S}$ & $47^{\circ} 59^{\prime} 24^{\prime \prime} \mathrm{W}$ & $601 \mathrm{~m}$ & T3 \\
\hline Tarumã & $22^{\circ} 44^{\prime} 56^{\prime \prime} \mathrm{S}$ & $50^{\circ} 34^{\prime} 42^{\prime \prime} \mathrm{W}$ & $429 \mathrm{~m}$ & T3/FAT \\
\hline Nova Europa & $21^{\circ} 46^{\prime} 52^{\prime \prime} \mathrm{S}$ & $48^{\circ} 33^{\prime} 57^{\prime \prime} \mathrm{W}$ & $502 \mathrm{~m}$ & T3/FAT \\
\hline Barra Bonita & $22^{\circ} 28^{\prime} 22^{\prime \prime} \mathrm{S}$ & $48^{\circ} 33^{\prime} 49^{\prime \prime} \mathrm{W}$ & $526 \mathrm{~m}$ & T3/FAT \\
\hline Guariba & $21^{\circ} 21^{\prime} 48^{\prime \prime} \mathrm{S}$ & $48^{\circ} 13^{\prime} 49^{\prime \prime} \mathrm{W}$ & 649 m & T3/FAT \\
\hline Guaíra & $20^{\circ} 19^{\prime} 31^{\prime \prime} \mathrm{S}$ & $48^{\circ} 18^{\prime} 39^{\prime \prime} \mathrm{W}$ & $518 \mathrm{~m}$ & FAT \\
\hline Américo Brasiliense & $21^{\circ} 43^{\prime} 26^{\prime \prime} \mathrm{S}$ & $48^{\circ} 06^{\prime} 07^{\prime \prime} \mathrm{W}$ & 715 m & FAT \\
\hline Olímpia & $20^{\circ} 44^{\prime} 13^{\prime \prime} \mathrm{S}$ & $48^{\circ} 54^{\prime} 39^{\prime \prime} \mathrm{W}$ & $480 \mathrm{~m}$ & FAT \\
\hline Cosmópolis & $22^{\circ} 38^{\prime} 45^{\prime \prime} \mathrm{S}$ & $47^{\circ} 11^{\prime} 45^{\prime \prime} \mathrm{W}$ & $652 \mathrm{~m}$ & FAT \\
\hline Paraguaçu Paulista & $22^{\circ} 24^{\prime} 48^{\prime \prime} \mathrm{S}$ & $50^{\circ} 34^{\prime} 32^{\prime \prime} \mathrm{W}$ & $509 \mathrm{~m}$ & FAT \\
\hline Piracicaba & $22^{\circ} 43^{\prime} 41^{\prime \prime} \mathrm{S}$ & $47^{\circ} 38^{\prime} 49^{\prime \prime} \mathrm{W}$ & $526 \mathrm{~m}$ & FAT \\
\hline
\end{tabular}




\section{PERFORMANCE}

Cultivar RB985476 has slow initial development and a semidecumbent growth pattern. The stalks are of medium diameter, are yellowish green in color, and have a green, slightly purplish, and lightly waxed sheath. Tillering capacity is high and exhibits longevity with good capacity of germination under mechanical harvesting besides good canopy cover. In addition, cultivar RB985476 also has a high agro-industrial yield (Table 2), yield stability, and medium to low fiber content. Under the climatic and soil conditions prevalent in south-central Brazil, the harvest may be occur between July and September (Figure 2). Furthermore, cultivar RB985476 eventually flowers and produces little to no pith.

RB985476 is responsive when allocated to better soils and climate. Agricultural yield (TCH) was determined to be higher than that of cultivar RB867515 in intermediate to favorable environments, and similar in more unfavorable environments (Figure 3). This response of RB985476 has been demonstrated in pre-commercial areas, and therefore cultivation of RB985476 is recommended in environments classified as intermediate and favorable by Prado (2008).

The agricultural yield (TCH) and sucrose content (PC in \%) produced by RB985476 cultivar were $126 \mathrm{t} \mathrm{ha}^{-1}$ and $15.3 \%$, respectively. The performance of agro-industrial yield (TPH) was superior to that of commercial standard cultivars of intermediate/late maturation, based on means of the data deriving from the three to four harvests included in the 13

Table 2. Means tons of cane per hectare (TCH) and tons of POL per hectare (TPH) of cultivars RB985476 and RB867515, according to the type of environment and crop cycle. Estimation of yield gain of cultivar RB985476 compared to cultivar RB867515. Mean results of 42 harvests in São Paulo state, Brazil

\begin{tabular}{|c|c|c|c|c|c|c|c|c|c|}
\hline \multirow{2}{*}{ Environments } & \multirow{2}{*}{ Crop cycle } & \multicolumn{4}{|c|}{ TCH } & \multicolumn{4}{|c|}{ TPH } \\
\hline & & RB985476 & RB867515 & Difference $^{1}$ & $\%$ & RB985476 & RB867515 & Difference & $\%$ \\
\hline \multirow{4}{*}{ All environments } & Plant-cane & 162.94 & 159.07 & 3.87 & 2.43 & 23.13 & 22.16 & $0.97^{*}$ & 4.38 \\
\hline & First-ratoon & 118.13 & 116.65 & 1.48 & 1.27 & 18.45 & 18.06 & $0.39 *$ & 2.16 \\
\hline & Second-ratoon & 106.00 & 99.07 & $6.93^{*}$ & 7.00 & 17.07 & 15.55 & $1.52 *$ & 9.77 \\
\hline & Mean & 129.80 & 126.22 & $3.58^{*}$ & 2.84 & 18.97 & 18.24 & $0.73^{*}$ & 4.00 \\
\hline \multirow{4}{*}{ Favorable environments } & Plant-cane & 178.71 & 172.64 & 6.07 & 3.52 & 25.11 & 23.82 & 1.29 & 5.42 \\
\hline & First-ratoon & 128.14 & 126.90 & 1.24 & 0.98 & 19.08 & 18.80 & 0.28 & 1.49 \\
\hline & Second-ratoon & 125.74 & 115.97 & $9.77^{*}$ & 8.42 & 20.17 & 17.85 & $2.32 *$ & 13.00 \\
\hline & Mean & 145.58 & 141.26 & 4.32 & 3.06 & 20.74 & 19.79 & $0.95^{*}$ & 4.80 \\
\hline \multirow{4}{*}{ Unfavorable environments } & Plant-cane & 144.55 & 143.24 & 1.31 & 0.91 & 20.81 & 20.22 & 0.59 & 2.92 \\
\hline & First-ratoon & 108.12 & 106.4 & 1.72 & 1.62 & 17.83 & 17.32 & 0.51 & 2.94 \\
\hline & Second-ratoon & 86.26 & 82.18 & $4.08^{*}$ & 4.96 & 13.98 & 13.25 & 0.73 & 5.51 \\
\hline & Mean & 111.41 & 108.68 & 2.73 & 2.51 & 16.91 & 16.43 & $0.48^{*}$ & 2.92 \\
\hline
\end{tabular}

${ }^{1}$ Difference between cultivar RB985476 and reference RB867515; * Significant at 5\% (t test).

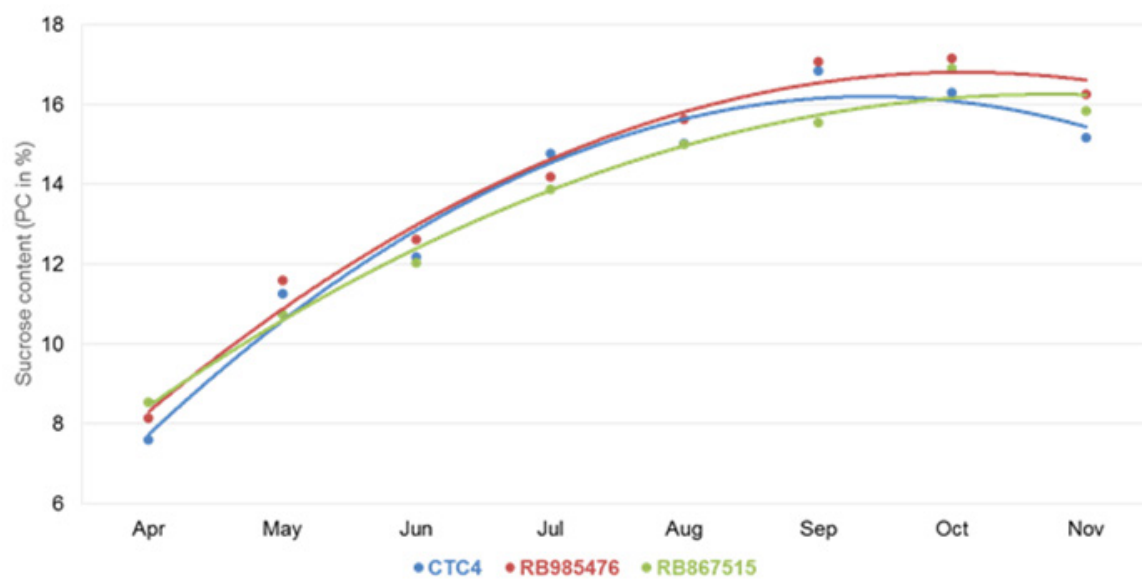

Figure 2. Comparison of the sugarcane cultivar RB985476 maturation curve with those of the commercial standard cultivars CTC4 and RB867515. 


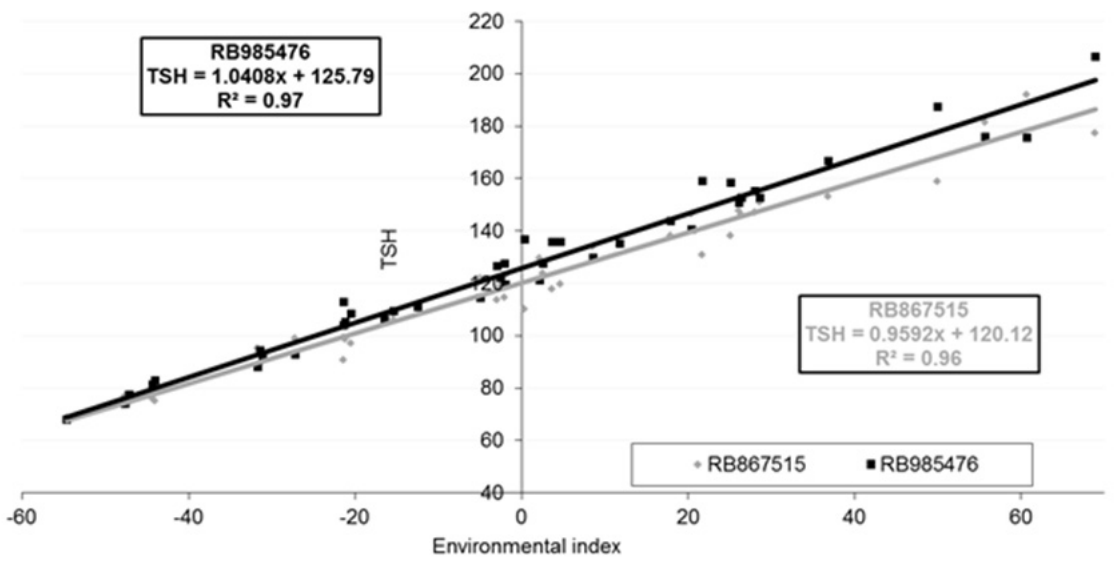

Figure 3. Comparison of cultivar RB985476 adaptability and stability with that of the commercial standard cultivar RB867515. Mean data of tons of cane per hectare (TCH) were adjusted based on regression analysis (Eberhart and Russell 1966). The points indicate the dataset of 13 experiments and a total of 41 harvests.

experiments.

\section{OTHER CHARACTERISTICS}

\section{Disease response}

RB985476 was evaluated to major sugarcane diseases through tests of artificial inoculation and natural infection, as a means of assessing the response against pathogens of the environments of south-central Brazil.

Natural tests were carried out in areas favorable to infection by several diseases due to climatic conditions and high inoculum pressure. Resistance to The main diseases evaluated under natural infection conditions were orange rust (Puccinia kuehnii), brown rust (Puccinia melanocephala), smut (Sporisorium scitamineum), leaf mosaic (sugarcane mosaic virus), and leaf scald (Xanthomonas albilineans) were assessed under conditions of natural infection. Evaluations were based on leaf area percentage with symptoms (\% severity) for orange and brown rusts (Amorim et al. 1987) and on the number of infected clumps (\% incidence) for smut, leaf mosaic, and leaf scald.

Greenhouse tests of artificial inoculation for smut and mosaic were conducted in accordance with the procedures according to Matsuoka (1979). Evaluations were based on a grade scale for each disease, which considers the amount of infected plants (\% incidence) and is used to classify the genotype as resistant, intermediate, or susceptible to infection by that pathogen. The results of the inoculation tests indicated that RB985476 is highly resistant to the rusts and smut, tolerant to leaf scald, and moderately resistant to leaf mosaic (Table 3). It is therefore recommended that this cultivar be planted without restriction.

In addition, analysis of extracted genomic DNA with R12H16 and 9020-F4-Rsal, two molecular markers commonly used in the diagnosis of Bru1, a gene associated with brown rust resistance (Costet et al. 2012), revealed the presence of the Bru1 gene in RB985476 (haplotype 1, Table 3).

\section{Basic seed maintenance and distribution}

Seedlings of cultivar RB985476 are maintained and distributed by the Sugarcane Breeding Program of the Federal University of São Carlos, Araras, São Paulo, Brazil, and have been registered with the RNC (\#36370) and SNPC (\#20170233). 


\section{REFERENCES}

Amorim L, Bergamin Filho A, Sanguino A, Cardoso CON, Moraes VA and Fernandes CR (1987) Metodologia de avaliação da ferrugem da cana-de-açúcar (Puccinia melanocephala). Boletim Técnico COPERSUCAR 39: 13-16.

Balsalobre TWA, Mancini MC, Pereira GS, Anoni CO, Barreto FZ, Hoffmann HP, Souza AP, Garcia AAF and Carneiro MS (2016) Mixed modeling of yield components and brown rust resistance in sugarcane families. Agronomy Journal 108: 1824-1837.

Brasileiro BP, Mendes TOP, Peternelli LA, Silveira LCI, Resende MDV and Barbosa MHP (2016) Simulated individual best linear unbiased prediction versus mass selection in sugarcane families. Crop Science 56: 570-575.

Carneiro MS, Chapola RG, Junior ARF, Cursi DE, Balsalobre TWA and Hoffmann HP (2019) RB005014 - a sugarcane cultivar with high tillering and agroindustrial yield. Crop Breeding and Applied Biotechnology 19: 230-234.

Carneiro MS, Chapola RG, Junior ARF, Cursi DE, Barreto FZ, Balsalobre TWA and Hoffmann HP (2016) RB975242 and RB975201 - Late maturation sugarcane varieties. Crop Breeding and Applied Biotechnology 16: 365-370.

Chapola RG, Fernandes Júnior AR, Cursi DE and Hoffmann HP (2016) Censo de variedades de cana-de-açúcar nos estados de São Paulo e Mato Grosso do Sul em 2015. STAB 34: 40-42.

Costet L, Le Cunff L, Royaert S, Raboin LM, Hervouet C, Toubi L, Telismart H, Garsmeur O, Rousselle Y, Pauquet J, Nibouche S, Glaszmann JC, Hoarau JY and D'Hont A (2012) Haplotype structure around Bru1 reveals a narrow genetic basis for brown rust resistance in modern sugarcane cultivars. Theoretical and Applied Genetics 125: 825-836.
Diniz CA, Ferreira VM, Barbosa GVS, Cruz MM, Silva JV, Santos JM, Teodoro I, Tôrres VLD, Soares L, Silva AMO, Nascimento BFC, Souza AJR, Ribeiro CA, Viveiros AJA, Sampaio Filho F and Freitas EG (2019) RB0442 - drought tolerant sugarcane cultivar. Crop Breeding and Applied Biotechnology 19: 466-470.

Daros E, Oliveira RA, Zambon JLC, Bespalhok Filho JC, Brasileiro BP, Ido OT, Ruaro L and Weber H (2018) RB036066 - a sugarcane cultivar with high adaptability and yield stability to Brazilian South-Central region. Crop Breeding and Applied Biotechnology 18: 325-329.

Daros E, Oliveira RA, Zambon JLC, Bespalhok Filho JC, Brasileiro BP, Ido OT, Ruaro L and Weber H (2017) RB036088 - a sugarcane cultivar for mechanical planting and harvesting. Crop Breeding and Applied Biotechnology 17: 84-88.

Eberhart SA and Russell WA (1966) Stability parameters for comparing varieties. Crop Science 6: 36-40.

Federer WT (1956) Augmented (or hoonuiaku) designs. Hawaian Planters' Record 55: 191-208.

Matsuoka S (1979) Método para pré-testagem de clones de cana-deaçúcar ao carvão e ao mosaico conjuntamente. In I Congresso nacional da sociedade dos técnicos açucareiros e alcooleiros do Brasil. STAB, Maceió, p. 231-233.

Morais LK, Aguiar MS, Silva PA, Câmara TMM, Cursi DE, Fernandes Júnior AR, Chapola RG, Carneiro MS and Bespalhok Filho JC (2015) Breeding of sugarcane. In Cruz VMV and Dierig DA (Eds) Industrial crops: breeding for bioenergy and bioproducts. Editora Springer, New York, p. 29-42.

Prado H (2008) Pedologia fácil: aplicações na agricultura. Hélio do Prado, Piracicaba, 45p.

(cc) EY This is an Open Access article distributed under the terms of the Creative Commons Attribution License, which permits unrestricted use, distribution, and reproduction in any medium, provided the original work is properly cited. 